Journal of Maternal and Child Health (2019), 4(1): 40-48

https://doi.org/10.26911/thejmch.2019.04.01.06

\title{
Factors Associated with Development in Children Under Five
}

\author{
Nikmah Ayu Ramadhani Amir1), Uki Retno Budihastuti²), Bhisma Murti1) \\ 1)Masters Program of Public Health, Universitas Sebelas Maret \\ 2)Department of Obstetrics and Gynecology, Dr. Moewardi Hospital, Surakarta
}

\begin{abstract}
Background: The first five years of a child's life are critical for development. The experiences children have in these years help shape the adults they will become. Parent relationship with their children plays a big part in the way children learn and develop. This study aimed to examine factors associated with development in children under five years of age.

Subjects and Method: This was a cross sectional study conducted at 20 posyandus (integrated health posts), Ngemplak, Boyolali, Central Java, from May 5 to June 10, 2018. A total sample of 203 children under five years of age was selected by simple random sampling. The dependent variable was child development. The independent variables were maternal age at pregnancy, prolonged labor, birthweight, birth asphyxia, and family income. Data on child development were measured by pre-screening questionnaire. The other variables were measured by questionnaire. The data were analyzed by a multilevel logistic regressionrun on Stata 13.

Results: Child development was positively affected by maternal age at pregnancy $(b=0.33 ; 95 \%$ $\mathrm{CI}=0.03$ to $0.64 ; \mathrm{p}=0.032)$ and absence of birth asphyxia $(\mathrm{b}=0.60 ; 95 \% \mathrm{CI}=0.16$ to $1.05 ; \mathrm{p}=$ 0.007), birthweight $(b=0.01 ; 95 \% \mathrm{CI}=-0.01$ to $0.01 ; \mathrm{p}=0.111)$, and family income $(\mathrm{b}=0.27 ; 95 \%$ $\mathrm{CI}=-0.04$ to $0.58 ; \mathrm{p}=0.087)$. Children development was negatively affected by prolonged labor $(b=-0.30 ; 95 \% \mathrm{CI}=-0.57$ to $-0.03 ; \mathrm{p}=0.029)$. Posyandu had a strong contextual effect on child development with $\mathrm{ICC}=16.16 \%$.

Conclusion: Child development is positively affected by maternal age at pregnancy and absence of birth asphyxia, birthweight, and family income. Children development is negatively affected by prolonged labor. Posyandu has a strong contextual effect on child development.
\end{abstract}

Keywords: child development, maternal age at pregnant, prolonged labor, birth asphyxia, birthweight, family income

\section{Correspondence:}

Nikmah Ayu Ramadhani Amir. Masters Program of Public Health, Universitas Sebelas Maret, Jl. Ir. Sutami 36 A, Surakarta 57126, Central Java. Email: ad1892nr@gmail.com.

Mobile: +6282323957575

\section{BACKGROUND}

Development is the result of a process of maturity and learning that has a regular and sequential pattern. Development includes 4 aspects, namely fine motoric, gross motoric, speech and language, and independence socialization (Soetjiningsih, 2014). Children development becomes the main foundation of productivity throughout a person's life, for example children who experience cognitive impairment are predictors of low learning achievement which later have the opportunity to have low income, high fertility, making it difficult to provide adequate care for their children (Pell et al., 2016 ).

National data shows that malnutrition prevalence is $19.6 \%$ and stunting / short is $37.2 \%$. In addition, the proportion of children under five who have never been weighed in the past six months has increased to $34.3 \%$ (Basic health research, 2013). The study shows that there is a significant relationship between growth disorders (poor nutrition, stunting) and developmental disorders. Every year, nearly 
200 million children under 5 years of age fail to achieve optimal development in lowand middle-income countries. Risk factors that interfere with development include poor cognitive stimulation, poverty, nutritional status, infection and complications of low birth weight (LBW) and or premature (Pell et al., 2016).

The first five years of life are times that are very sensitive to the environment, run fast, and will never be repeated, so it is often called the golden age. Growth and development at this time need serious attention. Children brain is more plastic than an adult's brain. This plasticity has a negative side and a positive side. Children are more open to the learning process but also very sensitive to the environment that does not support (Ministry of Health, 2013).

Monitoring the growth and development of children aged 12-59 months is carried out through early detection and intervention program for growth and development (SDIDTK) of children under five at least 2 times per year. The percentage of service for children under five in Central Java, in 2016, was 81.5 percent, a slight decrease compared to 2015 of 86.2 percent. Districts / cities with the lowest percentage of children under five are Brebes at $26.94 \%$ followed by Wonosobo 30.63\%, and Boyolali 43.08\% (Central Java Health Office, 2016). This study aimed to determine factors associated with child development in Boyolali, Central Java.

\section{SUBJECTS AND METHOD}

\section{Study Design}

This was an analytic observational study with a cross sectional design. The study was conducted on in Ngemplak community health center, Boyolali, Central Java, from May 5 to June 10, 2018.

\section{Population and Samples}

The population in this study were all children under five in Ngemplak Health Center, Boyolali. This study uses multilevel analysis, so the sampling was done at two levels. The sampling at the first level is children employing simple random sampling technique. Meanwhile, at the second level is posyandu using stratified random sampling technique in which 20 posyandu selected are divided into four strata, namely pratama, madya, purnama and independent strata. The sample size in this study was 203 children.

\section{Study Variables}

The dependent variable is the development of infants, while the independent variables are the age of the mother during pregnancy, prolonged labor, history of asphyxia, birth weight (BBL) and family income.

\section{Operational Definition of Variables}

Child development included gross motoric, fine motoric, speech and language, and socialization of independence. The data were measured by pre-screening development questionnaire (KPSP). The measurement scale was continuous.

Maternal age during pregnancy was defined as the period of life of the mother from birth to the time of birth delivery.

Prolonged labor was defined as labor that lasts more than 24 hours.

Birth weight was defined as infant's weight at birth which was weighed within one hour after birth.

A history of asphyxia was defined as a condition where newborns cannot breathe spontaneously and regularly.

Family income is the amount of family income that is used to fulfill the family needs in one month.

The instrument in this study was a to measure child development and questionnaire sheets which included maternal age during pregnancy, prolonged labor, history 
Journal of Maternal and Child Health (2019), 4(1): 40-48

https://doi.org/10.26911/thejmch.2019.04.01.06

of asphyxia, birth weight and family income.

\section{Data Analysis}

The data in this study were analyzed using multilevel analysis. The multilevel model provides a strong technical framework that can be used to analyze the correlation properties of variables and is relevant when predictors are measured together. The first level multilevel analysis is on individual characteristics, while the second level is at the posyandu. Furthermore, multilevel analysis was done to generate access as an effect of all levels was carried out by multiple logistic regression analysis multilevel models using the STATA 13 program.

\section{Research Ethics}

Research that uses humans as study subjects should not conflict with ethics. This study was declared ethically feasible by the Health Research Ethics Commission (KEPK) Sebelas Maret University Medical Faculty No. 70 / UNS27.6 / KEPK / 2018

Table 2. Results of Univariate Analysis

\begin{tabular}{|c|c|c|c|}
\hline No. & Characteristics & $\mathbf{N}$ & $\%$ \\
\hline \multirow[t]{4}{*}{1.} & Maternal Age & & \\
\hline & $<20$ years old & 9 & 4.5 \\
\hline & 20-35 years old & 171 & 84.2 \\
\hline & > 35 years old & 23 & 11.3 \\
\hline \multirow[t]{3}{*}{2.} & Prolonged labor & & \\
\hline & $\leq 24$ hours & 158 & 77.8 \\
\hline & $>24$ hours & 45 & 22.2 \\
\hline \multirow[t]{4}{*}{3 . } & Birth Weight & & \\
\hline & $<2500$ gram & 24 & 11.8 \\
\hline & 2500-4000 gram & 177 & 87.2 \\
\hline & $>4000$ gram & 2 & 2 \\
\hline \multirow[t]{3}{*}{4.} & A history of asphyxia & & \\
\hline & Yes & 20 & 9.9 \\
\hline & No & 183 & 90.1 \\
\hline \multirow[t]{3}{*}{5 . } & Family Income & & \\
\hline & $<\operatorname{Rp} 1,519,289$ & 51 & 25.1 \\
\hline & $\geq \operatorname{Rp} 1,519,289$ & 152 & 74.9 \\
\hline \multirow[t]{3}{*}{6.} & Child Development & & \\
\hline & Poor & 80 & 39.4 \\
\hline & Good & 123 & 60.6 \\
\hline
\end{tabular}

Table 2 shows that most of the maternal age during pregnancy are in their 20-35 for

\section{RESULTS}

\section{The Characteristics of Subjects}

Table 1 shows that most of the study subjects were female for about 106 children (52.2\%) with the age of children mostly aged $\geq 24$ months accounting for 107 (52.7\%).

Table 1. Study Subject Characteristics

\begin{tabular}{lcc}
\hline Characteristics & n & \% \\
\hline Gender & & \\
Male & 97 & 47.8 \\
Female & 106 & 52.2 \\
Children age & & \\
$<24$ months & 96 & 47.3 \\
$\geq 24$ months & 107 & 52.7 \\
\hline
\end{tabular}

\section{Univariate Analysis}

The description of univariate analysis show the general description of the data of each variable in nominal data including maternal age during pregnancy, prolonged labor, history of asphyxia, birth weight, family income, and child development. The results of univariate analysis can be seen in table 2. 
158 (77.8\%). Most of the children had birth weight 2500-4000 grams were 177 (87.2\%), did not have history of birth asphyxia (183, 90.1\%). The family income of most of the children under five years old is high, amounting to 152 (74.9\%). Most of children had appropriate development for their age which is about 123 (60.6\%).

\section{Bivariate Analysis}

Bivariate analysis showed the relationship between an independent variable (maternal age during pregnancy, prolonged labor, history of asphyxia, birth weight, family income) to the dependent variable (child development). The statistical test used is chi-square.

Table 3 shows the results of bivariate analysis of the factors associated with infant development including maternal age during pregnancy $(\mathrm{OR}=2.64 ; 95 \% \mathrm{CI}=1.22$ to $5.70 ; \mathrm{p}=0.011)$, prolonged labor $(\mathrm{OR}=$ $0.48 ; 95 \% \mathrm{CI}=0.23$ to $1.00 ; \mathrm{p}=0.034)$, birth history not asphyxia (OR= 3.21; 95\% $\mathrm{CI}=1.22$ to $8.45 ; \mathrm{p}=0.014$ ), and family income $(\mathrm{OR}=4.09 ; 95 \% \mathrm{CI}=2.09$ to 8.00 ; $\mathrm{p}<0.001)$. Birth weight was not significantly associated with child development $(\mathrm{OR}=0.79 ; 95 \% \mathrm{CI}=0.28$ to $2.12 ; \mathrm{p}=$ 0.378).

Table 3. The result of bivariate analysis of factors associated with child development

\begin{tabular}{|c|c|c|c|c|c|c|c|c|}
\hline \multirow{3}{*}{ Variable } & \multicolumn{4}{|c|}{ Child Development } & \multirow{3}{*}{$\mathbf{O R}$} & \multicolumn{2}{|c|}{$95 \%$ CI } & \multirow{3}{*}{$\mathbf{p}$} \\
\hline & \multicolumn{2}{|c|}{ Poor } & \multicolumn{2}{|c|}{ Good } & & Lower & Upper & \\
\hline & $\mathbf{n}$ & $\%$ & $\mathbf{n}$ & $\%$ & & Limit & Limit & \\
\hline \multicolumn{9}{|l|}{ Maternal MUAC } \\
\hline$<23.5$ & 28 & 50 & 28 & 50 & 1.83 & 3.41 & 0.98 & 0.041 \\
\hline$\geq 23.5$ & 95 & 64.6 & 52 & 35.4 & & & & \\
\hline \multicolumn{9}{|c|}{ Maternal Age at Pregnancy } \\
\hline$<20,>35$ years & 13 & 40.6 & 19 & 59.4 & 2.64 & 5.70 & 1.22 & 0.011 \\
\hline 20-35 years & 110 & $64 \cdot 3$ & 61 & 36.7 & & & & \\
\hline \multicolumn{9}{|l|}{ Prolonged labor } \\
\hline$\leq 24$ hours & 90 & 57 & 68 & 43 & 0.48 & 1.00 & 0.23 & 0.034 \\
\hline$>24$ hours & 33 & 73.3 & 12 & 26.7 & & & & \\
\hline \multicolumn{9}{|l|}{ Birth Weight } \\
\hline$<2500$ or $>4000 \mathrm{~g}$ & 17 & 66.4 & 17 & 34.6 & 0.79 & 2.12 & 0.28 & 0.378 \\
\hline $2500-4000 \mathrm{~g}$ & 106 & 59.9 & 71 & 40.1 & & & & \\
\hline \multicolumn{9}{|c|}{ History of Asphyxia } \\
\hline Yes & 7 & 36 & 1 & 66 & 3.21 & 8.45 & 1.22 & 0.014 \\
\hline No & 116 & 63.4 & 67 & 36.6 & & & & \\
\hline \multicolumn{9}{|l|}{ Family Income } \\
\hline Low & 18 & $35 \cdot 3$ & 33 & 64.7 & 4.09 & 8.00 & 2.09 & $<0.001$ \\
\hline High & 105 & 69.1 & 47 & 30.9 & & & & \\
\hline
\end{tabular}

\section{Multivariate Analysis}

Table 4 showed that child development was positively and significantly related to the maternal age at pregnancy $(b=0.33 ; 95 \%$ $\mathrm{CI}=0.03$ to $0.64 ; \mathrm{p}=0.032)$. Mothers who were pregnant at the age of 20-35 years old were more likely to have infants with appropriate development compared to mothers who were pregnant at the age of $<20$ or $>35$ years old.

There was a negative relationship between history of prolonged labor and child development which was statistically significant $(b=-0.30 ; 95 \% \mathrm{CI}=-0.57$ to o.03; $\mathrm{p}=0.029)$. Mothers with prolonged labor increased the risk of inappropriate child development. 
There was a relationship between birth weight and child development which was statistically insignificant $(b=0.01 ; 95 \%$ $\mathrm{CI}=-0.01$ to $0.01 ; \mathrm{p}=0.111)$. Children who were born with low birth weight have an inappropriate development.

There was a relationship between history of asphyxia and child development which was statistically significant $(b=0.60$; 95\% CI= 0.16 to $1.05 ; \mathrm{p}=0.007$ ). Children who have a history of non-asphyxic birth were more likely to have appropriate development compared to children with asphyxia.

There was a relationship between family income and child development

Table 4. The results of multilevel analysis of factors related to child development

\begin{tabular}{|c|c|c|c|c|}
\hline \multirow{2}{*}{ Independent Variable } & \multirow{2}{*}{ b } & \multicolumn{2}{|c|}{$95 \% \mathrm{CI}$} & \multirow[b]{2}{*}{$\mathbf{p}$} \\
\hline & & Upper Limit & Lower Limit & \\
\hline \multicolumn{5}{|l|}{ Fixed Effect } \\
\hline Maternal age at pregnancy (20-35 years) & 0.33 & 0.64 & 0.03 & 0.032 \\
\hline Prolonged labor & -0.30 & -0.03 & -0.57 & 0.029 \\
\hline Birth weight (2500-4000 g) & 0.01 & 0.01 & -0.01 & 0.111 \\
\hline Did not have asphyxia & 0.60 & 1.05 & 0.16 & 0.007 \\
\hline \multirow{2}{*}{\multicolumn{5}{|c|}{ Random effect }} \\
\hline & & & & \\
\hline \multicolumn{5}{|l|}{ Posyandu } \\
\hline Var (asphyxia) & 0.25 & 0.94 & 0.06 & \\
\hline Var (constant) & 0.11 & 1.15 & 0.01 & \\
\hline \multicolumn{5}{|l|}{ N Observation $=203$} \\
\hline \multicolumn{5}{|l|}{ Number of groups $=20$} \\
\hline Log likelihood $=-253.78$ & & & & \\
\hline $\mathrm{ICC}=16.16 \%$ & & & & \\
\hline
\end{tabular}

\section{DISCUSSION}

1. The relationship between maternal age at pregnancy and child development

The result of the study showed that there was a relationship between maternal age at pregnancy and child development. This was in line with a study by Pieters and Levenstond (2015), which stated that maternal age has an effect on fine motor development and social personalities for children aged 0-18 months. A study by Morinis et al. (2013) also showed that which was statistically insignificant $(b=$ $0.27 ; 95 \% \mathrm{CI}=-0.04$ to $0.58 ; \mathrm{p}=0.087$ ). High family income were more likely to have children with appropriate development because they were able to provide optimal nutrition and stimulation to their children.

Posyandu stratification had a strong contextual effect on child development with ICC $=16.16 \%$. This showed that Posyandu with mandiri and purnama strata increased the tendency of appropriate child development compared to Posyandu with pratama and madya strata. children who were born from teenage mothers ( $\leq 18$ years old) tend to experience delays in verbal abilities than children who were born from 25-34 years old mothers. This was due to lack of verbal stimulation between mother and child due to depression which was susceptible to occur in adolescent mothers. A study by Rahmawati et al. (2018) stated that maternal age at pregnancy affected child development through birth length.

Maternal readiness to take care of their children to achieve optimal growth 
and development became very important,especially in nurturing at the early ages of life.Getting married at a relatively young age with immature physical and psychological readiness did not only affect the lives of the women but would also have an impact on the lives of their children. At a relatively young age ( $<18$ years old), maternal (emotional) and cognitive readiness was still considered to be immature. This affected the maternal understanding of nurturing that would be applied to their children(Yunarsih and Quyumi, 2013).

\section{The relationship between pro- longed labor and child develop- ment}

The result of the study showed that there was a relationship between long history of parturition and child development. Mothers with a long history of parturition were more likely to have under-age children development than mothers who have no history of parturition $(b=-0.30 ; 95 \% \mathrm{CI}=-$ 0.57 to $-0.03 ; \mathrm{p}=0.029)$. Prolonged labor was one of the causes of maternal and fetal mortality. In mothers, it can caused infection, exhausted, dehydration, and post partum hemorrhage. In the fetus, it can caused infection, injury, and asphyxia (Ardhiyanti and Susanti, 2016).This could affect the development of the next child.

\section{The relationship between birth weight and child development}

The result of the study showed that there was a relationship between birth weight and child development. This was in line with a study by Arumsari (2013) which concluded thatbirth weight as a risk factor for global developmental delay (GDD) among child at the Polytechnic of Growth and Development in Dr. Soetomo Hospital, Surabaya. Other studies stated that low birth weight (LBW) was associated with developmental delay in children (Moonik et al, 2015; Zwicker et al, 2013).
Huang et al. (2013) who conducted a study to 8,389 Chinese children aged 4-7 years old stated that premature babies, birth weight, and postnatal growth (weight, height, head circumference) were not related to cognitive and behavioral development, whereas in aterm infants, birth weight and growth after birth were related to cognitive development and behavior. This happened because of a large difference in the number of samples between preterm infants $(n=654)$ and aterm infants $(n=$ 7735). In addition, the author explained other factors such as the adequacy of nutrition in the first 1000 days, growth hormone, environmental factors, social, and parental economic that could affect the development of cognitive and behavior.

\section{The relationship between history of asphyxia and child development}

The result of the study showed that there was a relationship between history of asphyxia and child development. This was in line with a study by Rai and Thakur (2013), which stated that asphyxia babies were more likely to experience hearing disorders. Zwicker et al. (2013) stated that the duration of ventilation use and oxygen delivery to LBW infants affected the occurrence of impaired coordination of motor development.

\section{The relationship between family income and child development}

The result of the study showed that there was a relationship between family income and child development. This was in line with a study by Morinis et al. (2013) which stated thatpoverty was a predictor of delay in cognitive development and low learning achievement.Taywade and Pisudde (2017) stated that family income affected the incidence of LBW. The results of the study stated that low birth weight babies were born from families with low economic status. Stunting and wasting in children 
also occurred mostly in families with low economic status (Nurliyana et al, 2016). Low economic status was associated with the ability to provide nutritious and sanitary food, and lack of hygiene would cause an enhancement in infections and stunting in children (Ernawati et al, 2014).

Other studies showed that family income did not affect the developmental delays. (Santri et al, 2014; Mooniket al, 2015; McDonald et al, 2016; Pieters and Levenstond, 2015). Santri et al. (2014) stated that child's development was not affected by the family's economic status, but it was affected by parental stimulation. The better the stimulation given by parents, the more it would spur the development of children to be better. Depression during pregnancy, premature birth, lack of "me time", and lack of parents interaction with children in playing and reading books were the risk factors for developmental delays in the first year of a child's life (McDonald et al, 2016).

\section{The relationship between pos- yandu and child development}

The result of multilevel analysis showed the score of ICC was $16.16 \%$, this showed that there was a contextual effect of Posyandu on child development. This was in line with a study by Sinta et al. (2017) which stated that Posyandu with mandiri strata increased the success of exclusive breastfeeding compared to Posyandu with madya and purnama strata.

In the Posyandu pocket book issued by the Ministry of Health RI, the activities of the Posyandu consisted of main activities and development activities. The main activities include maternal and child health, family planning, immunization, nutrition, and prevention of diarrhea. Development activities including Development of Toddler Families (DTF), Family Medicinal Plants (FMP), Elderly Family Development (EFD), and Early Childhood Education Program (ECEP). Posyandu targets include all community members, especially infants and children; pregnant women, postpartum mothers, and nursing mothers; reproductive age couples; and child's caregivers.

The result of the study by Indriati and Lidyawati (2014) stated that there was a relationship between the level of maternal participation in participating in Posyandu activities and children nutritional status. Hidayat and Jahari (2012) also stated that households that used Posyandu were more likely to have children with good nutritional status and low morbidity compared to those who did not use Posyandu.

\section{REFERENCES \\ Ardhiyanti Y, Susanti S (2016). Faktor ibu yang berhubungan dengan partus lama di RSUD Arifin Achmad Pekan- baru. Jurnal Kesehatan Komunitas. 3(2):83-87 \\ Arumsari DR (2013). Faktor risiko yang berhubungan dengan keterlambatan perkembangan global pada balita. journal.unair.ac.id p:28-40 \\ Dinas Kesehatan Jawa Tengah (2017). Profil kesehatan Provinsi Jawa Tengah tahun 2016. Semarang: Dinas Kesehatan Provinsi Jawa Tengah. \\ Ernawati F, Muljati S, Dewi M, Safitri A (2014). Hubungan panjang badan lahir terhadap perkembangan anak usia 12 bulan. Penel Gizi Makan. 37 (2): 109-118}

Hidayat TS, Jahari AB (2012). Perilaku pemanfaatan posyandu hubungannya dengan status gizi dan morbiditas balita. Buletin Penelitian Kesehatan. 40(1):1-10.

Huang C, Martorell R, Ren A, Li Z (2013). Cognition and behavioural development in early childhood: the role of birthweight and postnatal growth. 
International Journal of Epidemiology, 42: 160-171.

Indriati R, Lidyawati C (2017). Hubungan tingkat partisipasi ibu mengikuti posyandu dengan status gizi balita di Desa Mulur rt 03/VI Bendosari Sukoharjo. Kosala JIK. 5(1): 1-9.

Kementrian Kesehatan (2012). Ayo ke posyandu setiap ulan. Jakarta: Promkes.

(2013). Pedoman pelaksanaan stimulasi deteksi dini tumbuh kembang di tingkat pelayanan dasar. Jakarta: Direktorat Jenderal Pembinaan Kesehatan Masyarakat.

Khatun M, AlMamun A, Scott J, William GM, Clavarino A, Najman JM (2017). Do children born to teenage parents have lower adult intelligence? A prospective birth cohort study. PLoS ONE. 12(3): e0167395. doi:10.1371/journal.pone.0167395

McDonald S, Kehler H, Bayrampour H, Lee NF, Tough S (2016). Risk and protective factors in early child development: result from the all our babies (AOB) pregnancy cohort. Research in Developmental Disabilities 58: 20-3.

Moonik, Lestari H, Wilar R (2015). Faktorfaktor yang mempengaruhi keterlambatan perkembangan anak taman kanak kanak. Jurnal e-Clinic. 3(1): 124-132

Morinis J, Carson C, Quigley MA (2013). Effect of teenage motherhood on cognitive outcomes in children: a population-based cohort study. Archives of Disease in Childhood. 98: 959-964.

Nurliyana AR, Shariff ZM, Taib MNM, Gan WY, Tan KA (2016). Early nutrition, growth and cognitive development of infants from birth to 2 years in Malaysia: a study protocol. BMC Pediatrics 16:160
Pell LG, Bassani DG, Nyaga L, Njagi I, Wanjiku C, Thiruchselvam $\mathrm{T}$, et al. (2016). Effect of provision of an integrated neonatal survival kit and early cognitive stimulation package by community health workers on developmental outcomes of infants in Kwale County, Kenya: study protocol for a cluster randomized trial. BMC Pregnancy and Childbirth. 16: 265.

Pieters N, Levenstond M (2015). Factors comprimising development of children under five living in extreme poverty. Journal of food and nutrition sciences.

Rai N, Thakur N (2013). Universal screening of newborns to detect hearing impairment. International Journal of Pediatric Otorhinolaryngology 77: 1036-1041

Rahmawati VE, Pamungkasari EP, Murti B (2018). Determinants of stunting and child development in Jombang district. Journal of Maternal and Child Health. 3(1): 68-80

Santri A, Indriansari A, Girsang BM (2014). Faktor- faktor yang mempengaruhi pertumbuhan dan perkembangan anak usia toodler (1-3 tahun) dengan riwayat berat badan lahir rendah. Jurnal Ilmu Kesehatan Masyarakat. 5(1): 63-70

Sinta P, Salimo H, Pamungkasari EP (2017). Multilevel analysis on the biosocial and economic determinants of exclusive breastfeeding. Journal of Maternal and Child Health. 2(4): 356370.

Soetjiningsih (2014). Tumbuh Kembang Anak Edisi 2. Jakarta: EGC.

Taywade ML, Pisudde PM (2017). Study of sociodemographic determinants of low birth weight in Wardha district India. Clinical Epidemiology and Global Health. 5: 14-20. 
Journal of Maternal and Child Health (2019), 4(1): 40-48

https://doi.org/10.26911/thejmch.2019.04.01.06

Yunarsih, Quyumi E (2013). Pengaruh stimulasi tumbuh kembang ibu yang menikah usia muda terhadap pertumbuhan dan perkembangan anak usia di bawah lima tahun (balita). Jurnal ilmu kesehatan. 2(1):83-88.
Zwicker JG, Yoon SW, MacKay M, Thomas JP, Rogers M, Synnes AR (2013). Perinatal and neonatal predictors of development coordination disorder in very low birthweight children. Arch Dis Child. 98:118-122. 